\title{
ZOOM IN FATIGUE PADA MAHASISWA KEPERAWATAN SELAMA PERIODE PANDEMIC COVID-19
}

\author{
Mad Zaini ${ }^{1)}$, Supriyadi ${ }^{2}$ \\ ${ }_{1,2}$ Program Studi Ilmu Keperawatan, Fakultas Ilmu Kesehatan, \\ Universitas Muhammadiyah Jember, Jember, Indonesia \\ email: madzaini@unmuhjember.ac.id
}

\begin{abstract}
Abstrak
Kebijakan pembelajaran daring selama periode pandemi COVID-19 menjadi alternatif bagi perguruan tinggi supaya proses belajar mengajar dapat dilaksanakan. Dalam pelaksanaannya, pembelajaran daring di perguruan tinggi memiliki dampak positif dan negatif terutama di bidang kesehatan. Tujuan dari penelitian ini adalah untuk mengetahui terjadinya zoom in fatigue pada mahasiswa keperawatan Fakultas Ilmu Kesehatan Universitas Muhammadiyah Jember selama masa pandemic COVID-19. Desain penelitian ini adalah cross sectional. Hasil penelitian ini menunjukkan bahwa durasi waktu yang digunakan dalam pembelajaran daring memiliki korelasi yang signifikan terhadap terjadinya zoom in fatigue pada mahasiswa keperawatan selama periode pandemi COVID-19. Durasi waktu yang lama dalam pembelajaran daring membutuhkan perhatian yang lebih intens disertai informasi yang banyak melalui media daring menyebabkan beban kognitif dan energi yang lebih besar sehingga mengakibatkan terjadinya zoom in fatigue pada mahasiswa selama periode pandemi COVID-19.
\end{abstract}

Kata kunci: daring, fatigue, pandemic

\begin{abstract}
Online learning policies during the COVID-19 pandemic period became an alternative for universities so that the teaching and learning process could be carried out. In its implementation, online learning in university has positive and negative impacts, especially in the health sector. The purpose of this study was to determine the occurrence of zoom in fatigue in nursing students of the Faculty of Health Sciences, University Muhammadiyah of Jember during the COVID-19 pandemic. The design of this study was cross sectional. The results of this study indicate that the time duration of using online learning has a significant correlation with the occurrence of zoom in fatigue in nursing students during the COVID-19 pandemic period. The long duration in online learning requires more intense attention accompanied by a lot of information through online media causing a greater cognitive load and energy, it leads to a zoom in fatigue among students during the COVID-19 pandemic period.
\end{abstract}

Keywords: online learning, fatigue, pandemic

\section{PENDAHULUAN}

Pandemi COVID-19 yang melanda Indonesia sejak Maret 2020 silam menyebabkan perubahan di berbagai aspek kehidupan, termasuk dunia pendidikan. Berdasarkan surat edaran Menteri Pendidikan dan Kebudayaan RI Nomor 3692/MPK.A/HK/2020 dan surat edaran Rektor Universitas Muhammadiyah Jember Nomor 0504/EDR/II.3.AU/F/2020 bahwa seluruh kegiatan belajar mengajar di Universitas Muhammadiyah Jember menggunakan metode daring atau online sebagai upaya pencegahan penularan COVID-19. Kebijakan metode daring atau online selama masa pandemi bertujuan untuk memutus mata rantai penyebaran COVID-19 (Hasanah et al., 2020).
Namun demikian, kebijakan tersebut juga memiliki dampak negatif bagi mahasiswa. Dampak negatif dari metode daring atau online di bidang kesehatan adalah terjadinya kelelahan dan kecemasan yang disebabkan oleh penggunaan media pembelajaran online seperti aplikasi zoom (Dhir, A., Yossatorn, Y., Kaur, p., 2018). Perasaan lelah, gelisah atau cemas selama mengikuti pembelajaran daring menggunakan aplikasi zoom disebut zoom infatigue.

Zoom in fatigue adalah perasaan lelah, gelisah atau cemas selama mengikuti kegiatan video conference. Istilah zoom in fatigue sebenarnya tidak hanya terbatas pada penggunaan aplikasi zoom tetapi bisa juga keluhan-keluhan tersebut dirasakan pada saat menggunakan aplikasi whatsapp video call, 
google meets, skype, facetime serta platform pembelajaran daring lainnya. Meskipun sebagian mahasiswa sudah terbiasa menggunakan media daring atau online, namun ketika penggunaannya berlebih akan mengakibatkan ketidaknyamanan (Ri et al., 2016). Zoom in fatigue juga memicu terjadinya perubahan konsentrasi pada apa yang dikerjakan sehingga berakibat pada produktifitas seseorang. Dengan demikian, selama mahasiswa belajar dari rumah melalui media video conference, memungkinkan terjadinya penurunan ketrampilan akademik seshingga kompetensi mahasiswa tidak akan tercapai dengan baik (Malik, 2020).

Pembelajaran secara daring di Universitas Muhammadiyah Jember, bukan hanya tentang penguasaan teknologi dan materi perkuliahan tetapi juga berkaitan dengan kompetensi yang harus dikuasai sesuai dengan mata kuliahnya. Kompetensi tersebut tidak hanya diukur dari kemampuan kognitif tetapi juga kemampuan afektif dan psikomotor. Penggunaan media pembelajaran daring serta banyaknya kompetensi yang harus dikuasai oleh mahasiswa jurusan keperawatan memunculkan tekanan dan stress pada mahasiswa.

Pembelajaran daring menggunakan aplikasi zoom memerlukan perhatian intens pada kata- kata dan gambar atau video, karena tampilan seseorang hanya terlihat dari kepala hingga bahu. Perhatian intens selama proses pembelajaran daring juga sering terkendala kualitas gambar atau video yang kurang baik (Rahardjo et al., 2020). Bersamaan dengan materi yang disampaikan melalui daring serta kendala dari aplikasi zoom yang digunakan maka sangat berpotensi menimbulkan zoom in fatigue pada mahasiswa keperawatan. Hasil studi pendahuluan yang dilakukan pada 10 mahasiswa di Fakultas Ilmu Kesehatan Universitas Muhammadiyah Jember yang menjalani proses pembelajaran daring selama pandemi menunjukkan bahwa masahasiswa mengalami kelelahan, kecemasan sehingga berdampak pada ketrampilan akademik dan kompetensi mahasiswa.

Penelitian sebelumnya terkait penggunaan media daring pada pembelajaran lebih kepada penggunaan sosial media yang dikaitkan dengan masalah kesehatan. Di era pandemi COVID-19 seperti saat ini keterkaitan antara media pembelajaran daring, kegiatan akademik dan penyebaran COVID19 membuat persoalan menjadi lebih kompleks sehingga menyebabkan peserta didik lebih rentan mengalami masalah kesehatan termasuk fenomena zoom in fatigue. Penelitian ini adalah penelitian deskriptif korelasi yang bertujuan untuk mengetahui karakteristik responden berdasarkan tingkat usia, jenis kelamin, lama menggunakan media pembelajaran, jenis media pembelajaran daring yang digunakan, zoom in fatigue serta untuk mengetahui hubungan antara karakteristik tersebut dengan dengan terjadinya zoom in fatigue pada mahasiswa keperawatan selama periode pandemic COVID-19.

\section{METODE PENELITIAN}

Desain penelitian yang digunakan adalah deskriptif korelasi dengan menggunakan pendekatan cross sectional. Populasi dalam penelitian adalah mahasiswa keperawatan di Fakultas Ilmu Kesehatan Universitas Muhammadiyah Jember. Dari jumlah populasi diambil sampel sejumlah 221 responden secara purposive sampling. Analisa data bivariat menggunakan spearman's rho untuk mengetahui hubungan karakteristik responden dengan terjadinya zoom in fatigue pada mahasiswa keperawatan selama periode pandemi COVID-19. Penelitian ini telah dilakukan uji etik dan dinyatakan lolos etik dengan nomor 1188/KEPK/FIKES/IX/2020.

\section{HASIL DAN PEMBAHASAN}

Hasil penelitian ini meliputi deskripsi karakteristik responden berdasarkan tingkat usia, jenis kelamin, lama menggunakan media pembelajaran daring, jenis media pembelajaran daring yang digunakan serta terjadinya zoom in fatigue pada mahasiswa keperawatan Fakultas Ilmu Kesehatan Universitas Muhammadiyah Jember.

Tabel 1. Karakteristik responden berdasarkan usia, jenis kelamin, waktu dan jenis media daring $(\mathrm{n}=221)$

\begin{tabular}{lcc}
\hline \multicolumn{1}{c}{ Karakteristik } & Frekuensi & Persentase \\
\hline Usia & 124 & 56,1 \\
15-20 tahun & 95 & 43,0 \\
$21-25$ tahun & 2 & 0,9 \\
$>$ 25 tahun & & \\
Jenis kelamin & 54 & 24,4 \\
Laki-laki & 167 & 75,6 \\
Perempuan & & \\
Lama menggunakan & & \\
media pembelajaran & & \\
daring & 11 & 5,0 \\
< 1 jam/hari & 96 & 43,4 \\
1-2 jam/hari & 114 & 51,6 \\
$>$ 2 jam/hari & & \\
Jenis media & & \\
pembelajaran daring & & \\
yang digunakan & & 1,4 \\
WhatsApp & 3 & 35,0 \\
Zoommeeting & 210 & \\
Googlemeet & 8 & \\
\hline
\end{tabular}


Berdasarkan tabel 1, diketahui bahwa sebagian besar responden berusia 15-20 tahun, berjenis kelamin perempuan, menggunakan media pembelajaran >2 jam/hari dan sebagian besar media pembelajaran daring yang digunakan berupa zoom meeting.

Tabel 2. Deskripsi responden berdasarkan terjadinya zoom in fatigue $(\mathrm{n}=221)$

\begin{tabular}{cccccc}
\hline Variabel & $\mathbf{N}$ & $\begin{array}{c}\text { Mi } \\
\mathbf{n}\end{array}$ & Maks & Mean & $\begin{array}{c}\text { Std. } \\
\text { Deviation }\end{array}$ \\
\hline $\begin{array}{c}\text { Zoom in } \\
\text { fatigue }\end{array}$ & 221 & 5 & 15 & 9,69 & 2,107 \\
\hline
\end{tabular}

Berdasarkan tabel 2, dikatehui bahwa variabel zoom in fatigue memiliki nilai terendah sebesar 5 dan nilai tertinggi sebesar 15 dengan nilai rata-ratanya sebesar 9,69 dan standart deviasinya (tingkat sebaran data) sebesar 2,107. Hasil analisa bivariat pada penelitian dapat dilihat pada tabel berikut ini.

Tabel 3. Analisis hubungan karakteristik responden dengan terjadinya zoom in fatigue $(\mathrm{n}=221)$

\begin{tabular}{lcc}
\hline \multicolumn{1}{c}{ Variabel independen } & $\begin{array}{c}\text { Variabel } \\
\text { dependen }\end{array}$ & p value \\
\hline Usia & & 0,625 \\
Jenis kelamin & 0,553 \\
$\begin{array}{l}\text { Lama menggunakan media } \\
\text { pembelajaran daring }\end{array}$ & $\begin{array}{l}\text { Zoom in } \\
\text { fatigue }\end{array}$ & 0,013 \\
$\begin{array}{l}\text { Jenis media pembelajaran } \\
\text { daring }\end{array}$ & & 0,796 \\
\hline
\end{tabular}

Tabel 3 menunjukkan bahwa tidak ada hubungan yang bermakna antara karakteristik responden berdasarkan usia, jenis kelamin dan jenis media pembelajaran daring yang digunakan dengan terjadinya zoom in fatigue pada responden selama periode pandemi COVID-19. Sedangkan hubungan karakteristik responden berdasarkan lama menggunakan media pembelajaran daring dengan terjadinya zoom in fatigue menunjukkan hubungan yang bermakna ( $\mathrm{p}=0,013 ; \alpha=0,05)$.

Zoom in fatigue diartikan sebagai kondisi emosional yang dialami mahasiswa ketika merasa lelah sebagai akibat dari metode pembelajaran daring. Terjadinya fatigue pada individu bersifat subjektif dan dipengaruhi oleh banyak faktor. Faktor kelelahan dalam belajar disebabkan oleh dua faktor yaitu internal dan eksternal (Dhir, A., Yossatorn, Y., Kaur, p., 2018). Faktor internal adalah faktor yang berasa dari dalam diri, seperti perasaa bosan. Sedangkan faktor eksternal berasal dari luar diri individu seperti materi yang banyak, durasi belajar yang lama, lingkungan belajar yang monoton dan tidak kondusif (Du Plessis, 2019). Berdasarkan dua faktor tersebut, maka diasumsikan bahwa usia tidak mempengaruhi terjadinya fatigue pada mahasiswa selama pembelajaran daring.

Pada penelitian ini juga diperoleh informasi bahwa sebagian besar responden adalah perempuan. Laki-laki dan perempuan memiliki perbedaan dalam menerima setiap peristiwa yang terjadi, termasuk dalam pembelajaran daring tetapi antara laki-laki dan perempuan sering kali berespon secara maladaptif dalam pembelajaran daring (Marin, M.-F., Morin-Major, J.-K., Schramek et al., 2012).

Perbedaan penerimaan terhadap setiap peristiwa dapat dijelaskan bahwa laki-laki memiliki toleransi yang lebih besar dibandingkan perempuan. Toleransi yang tinggi dalam menerima materi perkuliahan cenderung menyebabkan bertambahnya tugas akademik. Tugas akademik yang tidak diselesaikan dimanajemen dengan baik akan mengakibatkan kelelahan atau fatigue (Zhou, M., \& Zhang, 2019). Sebaliknya seorang perempuan mempunyai kepekaan yang lebih tinggi terhadap informasi termasuk materi perkuliahan yang diberikan secara daring, sehingga wanita lebih reaktif dan merasa tertekan secara fisik dan emosi ketika menerima materi perkuliahan yang diberikan secara daring.

Sikap reaktif seorang perempuan dalam menerima informasi dalam bentuk materi perkuliahan serta beban akademik yang tinggi mengakibatkan kelelahan atau fatigue (Shokouhyar, S., Siadat, S. H., \& Razavi, 2018). Pada penelitian tersebut, yang mempengaruhi terjadinya fatigue adalah faktor jenis dan beban akademik yang tinggi.Peneliti berpendapat bahwa terjadinya fatigue dipengaruhi oleh faktor yang bersifat multidimensi, tidak hanya satu faktor. Hal tersebut sejalan dengan hasil penelitian ini yang menunjukkan bahwa tidak ada korelasi yang signifkan antara karakteristik jenis kelamin dengan terjadinya zoom in fatigue pada mahasiswa keperawatan selama pandemi COVID-19.

Karakteristik berikutnya pada penelitian ini adalah durasi waktu penggunaan media pembelajaran daring selama pandemic COVID-19. Pada penelitian ini menunjukkan bahwa sebagian besar responden menggunakan media pembelajaran daring selama $>2$ jam/hari. Penggunaan media daring dalam proses pembelajaran selama pandemi diyakini memberikan kemudahan belajar bagi mahasiswa dan menurunkan resiko penularan COVID-19. Namun demikian bukan berarti pembelajaran 
daring tidak memiliki resiko terhadap kesehatan, salah satunya adalah terjadinya kelelahan atau fatigue yang disebabkan terlalu lama menggunakan media pembelajaran daring (Guo, Y., Lu, Z., Kuang, H., \& Wang, 2020). Selama mengikuti pembelajaran daring, individu memerlukan perhatian yang intens pada media daring serta energi yang banyak agar dapat memproses materi atau informasi yang diberikan (Yu, L., Cao, X., Liu, Z., \& Wang, 2018). Perhatian yang lebih intens pada media pembelajaran daring dalam kurun waktu yang relatif lama rentan menimbulkan kelelahan atau fatigue pada mahasiswa. Kondisi tersebut sejalan dengan hasil penelitian ini yang menunjukkan bahwa ada korelasi yang signifkan antara karakteristik lama menggunakan media pembelajaran daring dengan terjadinya zoom in fatigue pada mahasiswa keperawatan selama pandemi COVID-19.

Disadari atau tidak, lamanya durasi waktu yang digunakan dalam pembelajaran daring berakibat pada fisik dan psikis mahasiswa. Salah satu dampak yang dialami mahasiswa adalah zoom in fatigue. Menerima dan memproses materi perkuliahan melalui media daring tidak mudah dilakukan oleh mahasiswa. Hasil studi yang dilakukan oleh Hwang, Hong, Tai, Chen dan Gouldthorp (2020) menjelaskan bahwa menerima dan memproses informasi yang cukup banyak serta dalam kurun waktu yang lama akan menyebabkan individu mengalami beban kognitif. Beban kognitif tersebut akan berpengaruh terhadap fisik dan emosi sehingga individu merasa kelelahan atau fatigue. Studi lain yang menguatkan tentang durasi penggunaan media daring juga dijelaskan oleh Guo, Lu, Kuang dan Wang (2020) yang juga menjelaskan bahwa lamanya individu menerima dan memproses informasi melalui media daring menyebabkan individu lebih rentan mengalami kelelahan atau fatigue.

Selama periode pandemi COVID-19 ini, pembelajaran dengan media daring menjadi alternatif bagi dunia pendidikan khususnya perguruan tinggi mengingat banyaknya informasi dan materi perkuliahan yang harus disampaikan kepada mahasiswa. Keharusan melihat dan menyimak informasi dan materi kuliah melalui media pembelajaran daring dalam kurun waktu yang lama membuat mahasiswa tidak mempunyai pilihan lain dan menempatkan media pembelajaran daring sebagai sesuatu yang krusial (Ahorsu, D. K., Lin, C. Y., Imani, V., Saffari, M. \& M. D., \& Pakpour, 2020).

Karakteristik berikutnya dalam penelitian ini adalah jenis media pembelajaran daring. Istilah zoom in fatigue pada penelitian ini tidak terbatas pada penggunaan media zoom meeting tetapi mencakup penggunaan media whatsapp video call, google meets serta platform pembelajaran daring lainnya (Aurora, A., \& Effendi, 2019). Dalam penelitian ini menunjukkan bahwa sebagian besar media pembelajaran daring yang digunakan dalam bentuk zoom meeting. Pembelajaran daring merupakan konsep belajar dari rumah yang diharapkan dapat membentuk kemandirian mahasiswa (Sianturi, 2018). Hasil penelitian ini menunjukkan bahwa tidak ada korelasi yang signifkan antara karakteristik jenis media pembelajaran daring dengan terjadinya zoom in fatigue pada mahasiswa keperawatan selama pandemi COVID-19. Selama belajar dari rumah diharapkan mahasiswa mampu memanajemen waktu belajar dengan baik, namun permasalahannya banyak mahasiswa yang tidak mampu mengelola waktu belajar meskipun banyak kemudahan dan media pembelajaran daring yang dapat digunakan selama pandemi COVID-19 ini. Dampak dari manajemen waktu belajar yang kurang baik adalah bertambahnya beban akademik sehingga memungkinkan terjadinya kelelahan atau fatigue, bukan karena jenis media pembelajarannya.

Tuntutan pembelajaran di masa pandemi dan cita-cita merdeka belajar membuat banyak mahasiswa belum mampu mengkombinasikan cara dan waktu belajar yang efektif sehingga mengakibatkan kelelahan atau fatigue. Kelelahan atau fatigue dalam proses pembelajaran merupakan kondisi emosional dimana individu merasa lelah secara fisik dan emosi yang disebabkan oleh multi faktor (Malik, 2020). Gejala dari kelelahan fisik diantaranya pusing, sendi-sendi otot yang kaku, sakit leher, insomnia serta gejala fisik lainnya. Sedangkan gejala emosi diantaranya timbulnya kebosanan, perasaan kecemasan serta ketakutan. Gejala fisik dan emosi tersebut menunjukkan bahwa pembelajaran dengan media daring menimbulkan kelelahan atau fatigue karena tidak hanya otak yang bekerja tetapi mata dan anggota tubuh yang lainnya ikut bekerja (Wahyu Rahardjo, 2020).

Peneliti berpendapat bahwa apapun media daring yang digunakan dalam pembelajar selama periode pandemi COVID-19 pada dasarnya sejalan dengan upaya pemerintah dalam menekan penyebaran COVID-19 dan cita-cita merdeka belajar sehingga belajar tidak lagi di ruang kelas tetapi bergeser ke ruang maya. Oleh karena itu dibutuhkan manajemen waktu yang baik guna mendapatkan hasil yang baik dalam proses belajar 
mengajar serta meminimalkan dampak negatif dari pembelajaran daring. Manajemen waktu belajar tidak hanya mengacu pada pengelolaan waktu saja tetapi bagaimana memanfaatkan waktu (Aurora, A., \& Effendi, 2019). Problematika manajemen waktu belajar bagi mahasiswa sangat diperlukan karena secara sosiologis mahasiswa berada pada keadaan yang rentan terhadap pengaruh eksternal salah satunya adalah media sosial (Sianturi, 2018).

Kebiasaan update status di whatsapp, instagram dan akses media sosial lainnya terkadang menjadi kebiasaan yang tidak terasa akan menghabiskan waktu belajar. Manajemen waktu yang baik sangat dibutuhkan supaya mahasiswa memiliki waktu istirahat dan belajar (Wardani, D.N., Toenlione, A.J.E \& Wedi, 2018). Mungkin pada saat mahasiswa istirahat di sela-sela pembelajaran daring mereka menggunakan juga untuk mengakses media sosial sehingga tugas dan tuntutan akademik tidak dapat diselesaikan akibatnya mahasiswa merasa tidak mempunyai waktu untuk kegiatan yang lain (Puspitasari, P., Sari, P., Putri, J., \& Wuryani, 2018). Ketika individu merasa kehilangan waktu untuk melakukan aktifitas sehari-hari maka akan semakin merasa kelelahan atau fatigue. Selain manajemen waktu yang kurang baik, tugas dan tuntutan akademik sering menyebabkan mahasiswa cemas. Kecemasan yang dialami akan meningkatkan tekanan psikis dan emosi sehingga memperburuk kelelahan atau fatigue.

\section{KESIMPULAN DAN SARAN}

Berdasarkan hasil penelitian ini, didapatkan bahwa sebagian besar responden adalah perempuan, berusia 15-20 tahun, durasi waktu yang digunakan dalam pembelajaran daring adalah $>2$ jam/hari serta sebagian besar menggunakan media pembelajaran berupa zoom meeting. Hasil analisis bivariat menunjukkan bahwa durasi waktu yang digunakan dalam pembelajaran daring memiliki korelasi yang signifikan terhadap terjadinya zoom in fatigue. Durasi waktu yang lama dalam pembelajaran daring membutuhkan perhatian yang lebih intens disertai informasi yang banyak melalui media daring menyebabkan beban kognitif dan energi yang lebih besar sehingga mengakibatkan terjadinya zoom in fatigue pada mahasiswa selama periode pandemi COVID-19. Oleh karena itu, peneliti merekomendasikan kepada penyelenggara pendidikan tinggi harus berinovasi dalam melaksanakan pembelajaran agar proses pendidikan tetap berlangsung. Salah satu upaya yang dapat dilakukan adalah dengan menerapkan kurikulum yang adaptif di perguruan tinggi. Upaya tersebut tidak hanya dilakukan penyelenggaran pendidikan tinggi, tetapi penyedia layanan kesehatan dan mahasiswa harus berperan aktif dalam mencegah terjadinya masalah-masalah seperti skrining atau penjaringan kesehatan kepada civitas akademik selama periode pandemic COVID-19 yang dilakukan oleh tenaga kesehatan.

\section{REFERENSI}

Ahorsu, D. K., Lin, C. Y., Imani, V., Saffari, M., G., \& M. D., \& Pakpour, A. H. (2020). The Fear of COVID-19 Scale: Development and initial validation. International Journal of Mental Health and Addiction. https://doi.org/https://doi.org/10.1007/s1146 9-020-00270- 8

Aurora, A., \& Effendi, H. (2019). Pengaruh Penggunaan Media Pembelajaran E-learning terhadap Motivasi Belajar Mahasiswa di Universitas Negeri Padang. JTEV (Jurnal Teknik Elektro Dan Vokasional), 05, 11-16.

Cao, X \& Yu, L. (2019). exploring the influence of excessive social media use at work: A threedimensions usage perspective. International Jurnal of Information Management, 46, 8392.

Dhir, A., Kaur, P., Chen, S., \& Pallesen, S. (2019). Antecedents and consequences of social media fatigue. International Journal of Information Management, 193-202. https://doi.org/https://doi.org/10.1016/j.ijinf omgt.2019.05.0 21

Dhir, A., Yossatorn, Y., Kaur, p., C. (2018). Online social media fatigue and psychological. International Jurnal of Information Management.

Dhir, A ., Kaur, p., Chen, S., Pallesen, S. (2019). Antecendents and consequences of social media fatigue. International Jurnal of Information Management, 48, 193-202.

Du Plessis, M. (2019). Coping with occupational stress in an open distance learning university in South Africa. Journal of Psychology in Africa, $\quad 6, \quad 570$ 575.https://doi.org/ttps://doi.org/10.1080/ 14330237.2019.1689466

El-seoud, M. S. A., Seddiek, N., El-khouly, M. M., \& Nosseir, A. (2009). E-Learning and Students ' Motivation: A Research Study on the Effect of E-Learning on Higher Education, 20-26. 
Guo, Y., Lu, Z., Kuang, H., \& Wang, C. (2020). Information avoidance behavior on social network sites: Information irrelevance, overload, and the moderating of time pressure. International Journal of Information Management. https://doi.org/https://doi.org/10.1016/ j.ijinfomgt.2020.102067

Handarini, O. I., \& Wulandari, S. S. (2020). Pembelajaran Daring Sebagai Upaya Study From Home (SFH) Selama Pandemi Covid 19. Jurnal Pendidikan Administrasi Perkantoran (JPAP), 8(3), 496-503.

Hasanah, A., Lestari, A. S., Rahman, A. Y., \& Daniel, Y. I. (2020). Analisis aktivitas belajar daring mahasiswa pada pandemi COVID-19.

Hidayat, A. A. (2014). Metode penelitian keperawatan dan teknis analisa data. Jakarta: Salemba Medika.

hifzul Muiz, M., \& Sumarni, N. (2020). Pengaruh Teknologi Pembelajaran Kuliah Online Di Era COVID-19 Dan Dampaknya Terhadap Mental Mahasiswa. EduTeach: Jurnal Edukasi Dan Teknologi Pembelajaran, 1(2), 153-165.

Malik, A. (2020). Correlates of social media fatigue and academic performance decrement A large cross-sectional study, 1707837. https://doi.org/10.1108/ITP-06-2019-0289

Marin, M.-F., Morin-Major, J.-K., Schramek, T. E., Beaupré, A., Perna, A., Juster, R.-P., \& Lupien, S., \& News:, J. (2012). There is no news like bad news: Women are more remembering and stress reactive after reading real negative news than men. PLOS ONE, $7(10)$.

https://doi.org/https://doi.org/10.1371/journal. pone.00471 89

McLean, K. C., \& Syed, M. (2015). Personal, Master, and Alternative Narratives: An Integrative Framework for Understanding Identity Development in Context. Human Development, $\quad 6, \quad 58$. https://doi.org/10.1159/000445817

Pawicara, R., \& Conilie, M. (2020). Analisis Pembelajaran Daring terhadap Kejenuhan Belajar Mahasiswa Tadris Biologi IAIN Jember di Tengah Pandemi COVID-19. ALVEOLI: Jurnal Pendidikan Biologi, 1(1), 29-38.
Puspitasari, P., Sari, P., Putri, J., \& Wuryani, W. (2018). Pengaruh penggunaan media pembelajaran terhadap motivasi belajar mahasiswa IKI Siliwangi. Parole: Jurnal Pendidikan Bahasa Dan Sastra Indonesia, 2, 227-232. https://doi.org/https://doi.org/ http://dx.doi.org/10.22460/p.v1i2p\%25p.243

Rahardjo, W., Qomariyah, N., Mulyani, I., \& Andriani, I. (2020). Early View Social media fatigue pada mahasiswa di masa pandemi COVID-19: Peran neurotisisme, kelebihan informasi, invasion of life, kecemasan , dan jenis kelamin, (59). https://doi.org/10.7454/jps.2020.xx

Ri, A., Son, S., \& Kyu, K. (2016). Computers in Human Behavior Information and communication technology overload and social networking service fatigue: A stress perspective, 55, 51-53.

Shokouhyar, S., Siadat, S. H., \& Razavi, M. K. (2018). How social influence and personality affect users'social network fatigue and discontinuance behavior. Aslib Journal of Information Management, 4, 344-366.

https://doi.org/ttps://doi.org/10.1108/AJIM11-2017-0263

Sianturi, S. R. (2018). Meningkatkan Motivasi Belajar Melalui Evaluasi E-Learning Pada Institusi Keperawatan Di Jakarta Dan Depok. Jurnal Pendidikan Keperawatan Indonesia, https://doi.org/https://doi.org/10.17509/jpki. v4i2.11563.

Sinaga, K. (2017). Penerapan Flipped Classroom Pada Mata Kuliah Kimia Dasar untuk Meningkatkan Self-Regulated Learning Belajar Mahasiswa. Jurnal Inovasi Pendidikan Kimia, 11(2).

Vannucci, A., Flannery, K. M., \& Ohannessian, C. M. (2017). Social media use and anxiety in emerging adults. Journal of Affective Disorders, 163-166. https://doi.org/https://doi.org/10. 1016/j.jad.2016.08.040

Wahyu Rahardjo, dkk. (2020). Social media fatigue pada mahasiswa di masa pandemi COVID-19: peran neurotisme, kelebihan informasi, invasion of life, kecemasan dan jenis kelamin. Jurnal Psikologi Sosial, 20. https://doi.org/10.7454/jps.2020.xx 
Wardani, D.N., Toenlione, A.J.E \& Wedi, A. (2018). Daya tarik pembelajaran di era 21 dengan blended learning. Jurnal Kajian Teknologi Pendidikan (JKTP), 1, 13-18.

Widiyono, A. (2020). Efektifitas Perkuliahan Daring (Online) pada Mahasiswa PGSD di Saat Pandemi Covid 19. Jurnal Pendidikan, 8(2), 169-177.

Yu, L., Cao, X., Liu, Z., \& Wang, J. (2018). Excessive social media use at work: Exploring the effects of social media overload on job performance. Nformation Technology \& People, 6, 1091-
1112. https://doi.org/https://doi.org/10.1108/ ITP-10- 2016-0237

Zahra, A. S., \& Wijayanti, S. (2020). Efektivitas Pembelajaran Basis Online di IAIN

Tulungagung dengan Adanya Kebijakan Psychal Distancing Era Pandemi Covid 19. GERAM, $8(1), 83-89$.

Zhou, M., \& Zhang, X. (2019). Online social networking and subjective well-being: Mediating effects of envy and fatigue. Computers \& Education. https://doi.org/598 https://doi.org/10.1016/j.compedu.2019.103 